ReseARCh NOTE

\title{
Lymnaea cubensis, an experimental intermediate host for Fascioloides magna
}

\author{
Philippe Vignoles ${ }^{1}$, Adam Novobilský ${ }^{2}$, Johan Höglund ${ }^{2}$, Martin Kašnýy $\dot{y}^{3,4}, J^{2}$ Pankrác ${ }^{3}$, Gilles Dreyfuss ${ }^{1}$, Jean- \\ Pierre Pointier $^{5}$ and Daniel Rondelaud ${ }^{1}$
}

\author{
${ }^{1}$ INSERM 1094, Faculties of Medicine and Pharmacy, Limoges, France; \\ ${ }^{2}$ Department of Biomedical Sciences and Veterinary Public Health, Section for Parasitology, Swedish University of Agricultural \\ Sciences (SLU), Uppsala, Sweden; \\ ${ }^{3}$ Department of Parasitology, Faculty of Science, Charles University, Prague, Czech Republic; \\ ${ }^{4}$ Department of Botany and Zoology, Faculty of Science, Masaryk University, Brno, Czech Republic; \\ ${ }^{5}$ Tropical and Mediterranean Biology and Ecology, USR 3278 CNRS-EPHE, University Via Domitia, Perpignan, France
}

\begin{abstract}
Single-miracidium infections of Lymnaea cubensis (Pfeiffer) from Guadeloupe with the giant liver fluke Fascioloides magna (Bassi, 1875) (Digenea) were carried out during five successive snail generations to determine if this lymnaeid might sustain complete larval development of the parasite. Controls were constituted by a French population of Galba truncatula (Müller) (a single generation) infected according to the same protocol. It was recorded that prevalence and intensity of F. magna infection in L. cubensis progressively increased from F1 to F5 generations. Cercarial shedding of $F$. magna was noted only within F5 generation of L. cubensis. However, most measured parameters of infection in this species were significantly lower than those noted for $G$. truncatula and most L. cubensis died after a single shedding wave. Despite this, L. cubensis can be added to the list of potential intermediate hosts of $F$. magna.

Keywords: giant liver fluke, experimental infections, Galba truncatula, snail generation, snail susceptibility
\end{abstract}

The success of a snail infection by a given digenean (Digenea) mainly depends on the susceptibility of this snail as an intermediate host (an interpopulation variability in susceptibility exists for many snail species) and the infectivity of miracidia (Smyth and Halton 1983). If a snail species other than the common snail host is used for infection, the process often results in abortive infections, but sometimes it may lead to development of infections with an increased production of cercariae.

In the case of the liver fluke, Fasciola hepatica Linnaeus, 1758, three South American lymnaeids, Lymnaea neotropica Bargues, Artigas, Mera y Sierra, Pointier et Mas-Coma, L. viatrix var. ventricosa d'Orbigny and $L$. cubensis (Pfeiffer) are known to sustain larval development of $F$. hepatica - see Morales and Pino (1983) and Bargues et al. (2007). Two of these snail species, L. neotropica and $L$. v. ventricosa, can also ensure larval development of the giant liver fluke Fascioloides magna (Bassi, 1875) (Digenea: Fasciolidae) (Sanabria et al. 2013), which is relatively close to $F$. hepatica.

This finding implicated the question as to whether other semiaquatic lymnaeids living in the New World such as L. cubensis would also sustain complete larval development of $F$. magna. This assumption is supported by the fact that $L$. cubensis is morphologically similar and genetically close to $L$. neotropica and L. v. ventricosa - Correa et al. $(2010,2011)$, and that it is susceptible to F. hepatica infection (Morales and Pino 1983, Bargues et al. 2007). Therefore, we followed the former experiments with L. neotropica/L. V. ventricosa and F. hepatica/F. magna and performed the additional experimental infections of a Guadeloupean population of L. cubensis with F. magna.

This lymnaeid was selected as a model for the following reasons: (i) F. magna was known to be enzootic in the south-eastern part of North America, i.e. lower Mississippi and around the coast of the Gulf of Mexico (Pybus 2001); (ii) the geographical distribution of $L$. cubensis covers the southeastern part of North America, the Caribbean and the northern part of South America (Dillon et al. 2006); (iii) a case of an imported wapiti was reported in Cuba (Lorenzo et al. 1989); and (iv) since there is evidence of significantly overlapping geographical distributions of the parasite $F$. magna and the snail L. cubensis, the susceptibility of this lymnaeid to F. magna infection and its potential role in transmission of fascioloidosis have to be tested.

Single-miracidium infections of this species with F. magna were thus carried out during five snail generations (from F1 to F5) to determine if larval development of this parasite can be complete in this lymnaeid and, if so, to specify the characteristics of snail infections. French Galba truncatula (Müller) infected during a single snail generation with the same miracidial isolate and raised according to the same protocol served as control.

The population of $L$. cubensis was living in a swampy zone bordering a mangrove at Pico $\left(16^{\circ} 21^{\prime} 13^{\prime \prime} \mathrm{N} ; 61^{\circ} 27^{\prime} 40^{\prime \prime} \mathrm{W}\right)$, commune of Morne-à-l'eau in Guadeloupe (French West Indies). Adult snails were collected in February 2012 before being raised in the laboratory at $22-24^{\circ} \mathrm{C}$ according to the method by Rondelaud et al. (2007). Five successive snail generations (F1-F5) of this species were used for experimental infections. The population of G. truncatula colonized a road ditch at Chézeau Chrétien (46 $46^{\circ} 27^{\prime \prime N}$; $1^{\circ} 21^{\prime} 21^{\prime \prime E}$ ), commune of Chitray, department of 
Table 1. Characteristics of Fascioloides magna infection in four generations of Lymnaea cubensis subjected to single-miracidium infections, raised at $22-24^{\circ} \mathrm{C}$ and dissected at day 50 p.e. (post exposure; experiment A).

\begin{tabular}{lcccc}
\hline & \multicolumn{4}{c}{ Generation of Lymnaea cubensis } \\
\cline { 2 - 5 } Parameters & F1 & F2 & F3 & F4 \\
\hline Number of snails & 50 & 50 & 50 & 50 \\
- at exposure & $18(36)$ & $25(50)$ & $29(58)$ & $27(54)$ \\
- at day 50 p.e. (rate in \%) & & & & \\
Number of infected snails & - & - & - & 10 \\
- with immature rediae & - & 7 & 9 & 5 \\
- with cercariae-containing rediae & 3 & 1 & 3 & 2 \\
- with free cercariae & 17 & 35 & 41 & 63 \\
Overall prevalence of infection (\%) & & & &
\end{tabular}

Indre, central France. This population was already used for experimental infections with F. magna by Sanabria et al. (2013).

Fifty snails (shell height $4 \mathrm{~mm}$ ) for the F1, F2, F3 or F4 generations of L. cubensis (Table 1), 100 for the F5 generation and 100 for G. truncatula (Table 2) were collected from each population. Eggs of $F$. magna were collected from adult flukes recovered from the livers of naturally infected red deer (Cervus elaphus Linnaeus) hunted near the village of Mirošov, Central Bohemia, Czech Republic. The eggs were washed several times with spring water and were incubated for 20 days at $20^{\circ} \mathrm{C}$ in the dark (Ollerenshaw 1971).

The susceptibility of $L$. cubensis to $F$. magna miracidia was studied during five successive snail generations (from $F 1$ to F5) via an experimental protocol already used by Sanabria et al. (2012) for $F$. hepatica. The F2 snails originated from eggs laid by infected individuals of $F 1$ generation between weeks 2 and 5 post-exposure (p.e.). A similar protocol was used for F3, F4 and F5 generations. This protocol was chosen because these descendants had a first contact (F2) or multiple (F3-F5 generations) contacts with the parasite through their infected parents.

Two experiments, A and B, were carried out. Four groups of 50 snails each (one group per snail generation from $\mathrm{F} 1$ to $\mathrm{F} 4$, Table 1) were constituted in experiment A. Single-miracidium infections were performed for each snail for 4 hours at $20^{\circ} \mathrm{C}$ in $3.5 \mathrm{ml}$ of spring water. Snails were then raised in groups of 10 individuals in $14 \mathrm{~cm}$ Petri dishes (volume of spring water, $60 \mathrm{ml}$ ) for 50 days according to the method by Rondelaud et al. (2007). Snail food consisted of dried leaves of lettuce and dead leaves of Molinia caerulea (Linnaeus), whereas several stems of live Fontinalis sp. ensured oxygenation of the water layer. Dissolved calcium in spring water was $35 \mathrm{mg} / \mathrm{l}$.

Petri dishes were placed in an air-conditioned room under the following conditions: a temperature of $22-24^{\circ} \mathrm{C}$, natural photoperiod of 10 hours light. At day 50 p.e., the surviving L. cubensis were dissected under a stereomicroscope to detect the presence of F. magna larval forms within their bodies and determine the most developed stage (immature rediae, cercariae-containing rediae, or free cercariae). Infected snails were then counted taking into account snail generation and each developmental stage of larval development.

The aim of experiment B was to follow the dynamics of F. magna cercarial shedding in experimentally infected snails until their natural death. One hundred snails belonging to F5 generation of $L$. cubensis and $100 \mathrm{G}$. truncatula were used. The shell height of these snails was measured using callipers just before miracidial exposure to use $4 \pm 0.1 \mathrm{~mm}$ high individuals only. Snail exposure to miracidia and snail breeding during the first 30 days p.e. were similar to those in experiment A. At day 30 , each surviving snail was isolated in a $35-\mathrm{mm}$ Petri dish to easily count metacercariae on dish bottom and walls during the patent period. Pieces of dead grass, lettuce and spring moss were put in these $35-\mathrm{mm}$ dishes, which were also placed at $22-24^{\circ} \mathrm{C}$. A daily surveillance was made to change spring water and food if necessary. As cercarial shedding of F. magna from experimentally-infected snails under laboratory conditions was sporadically reported (Erhardová-Kotrlá 1971, Vignoles et al. 2006), the surviving snails were subjected to a thermal shock to stimulate cercarial exit when the first cercarial shedding occurred.

To avoid a possible too high mortality of $L$. cubensis infected with $F$. magna, the temperature used for inducing the thermal shock was chosen according to temperature range prevailing in the natural habitat of $L$. cubensis. Petri dishes containing surviving snails were thus placed at $15-18^{\circ} \mathrm{C}$ for 3 hours according to the indications by Rondelaud et al. (2013) and Sanabria et al. (2013). After the replacement of Petri dishes at $22-24^{\circ} \mathrm{C}$, cercariae exited from the snails in the following 2-3 hours and metacercariae were counted before their removal from Petri dishes. At the death of each infected snail (between days 81 and 95 p.e. for L. cubensis, and between days 82 and 99 p.e. for G. truncatula), its shell was again measured using callipers. Cadavers of snails containing cercariae but without shedding (NCS snails) were then routinely dissected under a stereomicroscope to count free rediae and free cercariae.

The first parameter calculated was snail survival at day 50 p.e. (date of snail dissection) in experiment $A$ or at day 30 in experiment $\mathrm{B}$. The choice of day 30 for experiment $\mathrm{B}$ was due to the fact that several $F$. magna cercariae may sometimes exit from infected snails before day 50 p.e. (D. Rondelaud, INSERM 1094, Faculties of Medicine and Pharmacy, Limoges, France personal observation). Another parameter was prevalence of F. magna infection calculated in relation to the number of snails surviving at day 50 (A) or at day 30 (B). The numbers of snails with immature rediae only, cercariae-containing rediae, or with free cercariae (experiment A) and the quantities of cercariaeshedding snails (CS snails) and NCS snails dying after day 30 p.e. (experiment B) were concerned for prevalence calculation. For each parameter, the differences were analysed using a $\chi^{2}$ test. In experiment $\mathrm{B}$, the other parameters calculated were the shell growth of CS and NCS snails during the experiment (the difference between shell height at miracidial exposure and that measured at snail death), the length of the prepatent period for CS snails, that of the patent period, and the total number of metacercariae.

As cercarial shedding of $F$. magna was discontinuous during the patent period, with shedding waves (1-2 days each) separated by interwaves with no shedding (Vignoles et al. 2006), the number of CS snails showing a single or several shedding waves was considered. Lastly, free rediae and free cercariae counted in the cadavers of NCS snails were also taken into account. Individual values recorded for the shell growth of CS and NCS snails, the prepatent and patent periods, the total number of metacercariae, and the quantity of free rediae and free cercariae in NCS snails were averaged and their standard deviations were calculated considering snail groups. One-way analysis of variance (ANOVA) was used to establish levels of statistical signifi- 
Table 2. Characteristics of Fascioloides magna infection in F5 generation of Lymnaea cubensis and in Galba truncatula subjected to single-miracidium infections and raised at $22-24^{\circ} \mathrm{C}$ (experiment B).

\begin{tabular}{llll}
\hline Parameters & L. cubensis, F5 & G. truncatula & Statistics \\
\hline Number of snails & & & \\
- at exposure & 100 & 100 & - \\
- at day 30 p.e. (rate in \%) & $54(54)$ & $74(74)$ & $\chi^{2}=8.68, P<0.01$ \\
Number of snails after day 30 p.e. & 8 & 41 & - \\
- CS & 7 & 11 & - \\
- NCS & 39 & 18 & - \\
- Uninfected & 28 & 70 & $\chi^{2}=22.60, P<0.001$ \\
Prevalence of infection (\%) & $2.8(0.7)$ & $3.5(0.7)$ & $F=4.21, P<0.05$ \\
Shell growth (mm) during the experiment* & $3.4(0.6)$ & $F=4.11, P<0.05$ \\
- CS & $76.1(13.5)$ & $66.3(7.1)$ & $\mathrm{NS}$ \\
- NCS & $14.2(3.7)$ & $24.0(4.6)$ & $F=11.07, F<0.01$ \\
Prepatent period in days* & $61.0(31.1)$ & $107.9(41.2)$ & $F=4.05, P<0.05$ \\
Patent period in days* & & & \\
Number of metacercariae* & $21.9(5.2)$ & $36.5(6.2)$ & $\mathrm{NS}$ \\
Cadavers of NCS snails & $112.4(23.2)$ & $177.3(35.0)$ & $F=9.26, P<0.01$ \\
- Free rediae* & & & \\
- Free cercariae* & & &
\end{tabular}

* mean value (SD); CS - cercariae-shedding snails; $F$ - value of ANOVA; NCS - snails containing cercariae but without shedding; NS - not significant; $\mathrm{P}$ - probability; $\chi^{2}$ - value of the $\chi^{2}$ test.

Table 3. Numbers of cercariae-shedding (CS) snails belonging to Lymnaea cubensis (F5 generation) and Galba truncatula in relation to the number of shedding waves noted during the patent period (experiment B). $n$, total number of cercariae-shedding snails.

\begin{tabular}{ccc}
\hline \multirow{2}{*}{$\begin{array}{c}\text { No. of shedding waves } \\
\text { during the patent period }\end{array}$} & \multicolumn{2}{c}{ Number of CS snails } \\
\hline 1 & 6 & 2 \\
2 & 2 & 7 \\
3 & 0 & 18 \\
4 & 0 & 9 \\
5 & 0 & 5 \\
\hline
\end{tabular}

cance. Both types of analyses were calculated using the Statview 5.0 software (SAS Institute Inc., Cary, NC, USA).

Table 1 gives the numbers of infected snails in F1 to F4 generations infected with F. magna. The differences between survival rates at day 50 p.e. were insignificant, whatever the mode of comparison. In contrast, the number of snails with larval forms increased with increasing snail generation so that overall prevalence of infection was significantly greater $\left(\chi^{2}=10.13\right.$, $P<0.05)$ in $\mathrm{F} 4$ generation than in the other generations. If three snails of the F1 generation harboured immature rediae, most differentiated larval forms were noted in the further generations, with presence of free cercariae in two F4 snails.

The characteristics of $F$. magna infection in F5 generation of $L$. cubensis and in G. truncatula are given in Table 2. Survival of $L$. cubensis at day 30 p.e. and prevalence of infection were significantly lower than for the other snail species. Similar findings were also noted for the shell growth of CS and NCS L. cubensis during the experiment. No significant difference between the prepatent periods was found, even if the mean length noted for L. cubensis (76 days) was higher. Compared to values noted for G. truncatula, significantly shorter patent periods and lower numbers of metacercariae were noted for L. cubensis. Compared to NCS G. truncatula, the number of free cercariae in the body of NCS L. cubensis was significantly lower, while the redial burdens did not significantly differ from each other.
Six CS L. cubensis (out of 8) died after a single shedding wave during the patent period (Table 3), while the death of most CS G. truncatula occurred after two (7 snails), three (18 individuals), four ( 9 snails) or five (5 individuals) shedding waves.

The Guadeloupean population of $L$. cubensis used in the present study was able of sustaining complete larval development of the parasite, including the cercarial shedding under experimental conditions. However, the infection of five successive generations of snails was necessary to have a progressive increase in prevalence and intensity of $F$. magna infection. This finding suggests a progressive adaptation of this population to the parasite through several successive snail generations, as already reported by Dreyfuss et al. (2010) for Lymnaea glabra Müller. This progressive adaptation of $L$. cubensis to the parasite might be related to a change in the host immune response, which will gradually remove the bottleneck exerted by the snail body on parasite development. This hypothesis is supported by the work of Szmidt-Adjidé et al. (1996) on infected G. truncatula. According to these authors, many neurons of the cerebroid and pedal ganglia would degenerate and lost the function during snail infection. According to this assumption, the ganglia of $L$. cubensis would secrete a lower and lower amount of neuromediators through successive generations of infected snails and thus induce a progressive change in the mechanisms of immune system response to the parasite and a progressive lifting of the bottleneck exerted by the snail on larval development of the parasite. However, a decrease in L. cubensis resistance due to the conditions of snail breeding in the laboratory cannot be completely excluded.

Compared to control G. truncatula, most characteristics of infection in F5 generation of L. cubensis (Table 2) were significantly lower. The most surprising point was the low shell growth of CS and NCS L. cubensis during snail infection (2.6-2.8 mm, Table 2), whereas the corresponding shell growth of CS and NCS G. truncatula was $3.4-3.5 \mathrm{~mm}$. To explain this difference, it is necessary to realize that breeding conditions used to raise G. truncatula in the laboratory (Rondelaud et al. 2007, 2009) were not probably absolutely ideal for $L$. cubensis and that the particular elements (possibly a kind of nutrition that the lymnaeid meets in its natural habitat) may have been lacking in this breeding protocol. 
In experiment $\mathrm{B}$, the number of cercariae shed by CS L. cubensis and that of free cercariae present in NCS L. cubensis were also significantly lower than those noted for control G. truncatula. These two findings in L. cubensis can be explained by the lower shell growth of these infected snails during the experiment and, consequently, by the lower number of free rediae that developed within their bodies. Indeed, it is well known that a positive relationship between the shell growth of infected snails and cercarial production exists in some snail-parasite models, as demonstrated by Zischke (1967) for Echinostoma revolutum (Frölich, 1802) or by Rondelaud and Barthe (1987) for F. hepatica. However, in spite of these differences, L. cubensis seems to be suitable intermediate host for larval development of F. magna, similarly to $L$. v. ventricosa - Sanabria et al. (2013).

Cercariae from six CS L. cubensis (out of 8) were shed during a single wave just before the death of snails (Table 3 ), whereas cercariae from 39 CS G. truncatula (out of 41) were released during 2-5 shedding waves. These findings can also be explained by the above hypothesis of a progressive adaptation of this L. cubensis population to F. magna. An argument supporting this assumption is the occurrence of numerous $F$. hepatica cercarial shedding waves in the case of G. truncatula, the dominant snail host in Europe for $F$. hepatica (see Dreyfuss and Rondelaud 1994), whereas there are some records of lower number of shedding waves in the case of unusual snail hosts such as L. glabra or Planorbis leucostoma Kozkov (see Abrous et al. 1998). In conclusion, since L. cubensis was successfully experimentally infected, it can be added to the list of potential intermediate host of $F$. magna.

Acknowledgements. This study was supported by the Swedish Foundation for Agricultural Research (contract H1050003) and the Charles University in Prague (UNCE 204017, PRVOUK P41 and SVV 267210/2013).

\section{References}

Abrous M., Rondelaud D., Dreyfuss G., Cabaret J. 1998: Unusual transmission of the liver fluke, Fasciola hepatica, by Lymnaea glabra or Planorbis leucostoma in France. J. Parasitol. 84: 12571259.

Bargues M.D., Artigas P., Mera y Sierra R.L., Pointier J.P., MasComa S. 2007: Characterisation of Lymnaea cubensis, L. viatrix and $L$. neotropica n. sp., the main vectors of Fasciola hepatica in Latin America, by analysis of their ribosomal and mitochondrial DNA. Ann. Trop. Med. Parasitol. 101: 621-641.

Correa A.C., Escobar J.S., Durand P., Renaud F., David P., Jarne P., Pointier J.P., Hurtrez-Boussès S. 2010: Bridging gaps in the molecular phylogeny of the Lymnaeidae (Gastropoda: Pulmonata), vectors of fascioliasis. BMC Evol. Biol. 10: 381.

Correa A.C., Escobar J.S., Noya O., Velásquez L.E., GonzÁlezRamírez C., Hurtrez-Boussès S., Pointier J.P. 2011: Morphological and molecular characterization of Neotropic Lymnaeidae (Gastropoda: Lymnaeoidea), vectors of fasciolosis. Infect. Genet. Evol. 11: 1978-1988.

Dillon R.T. JR., Watson B.T., Stewart T.W., Reeves W.K. 2006: The Freshwater Gastropods of North America. World Wide Web electronic publication, www.fwgna.org, 08/2013.

Dreyfuss G., Rondelaud D. 1994: Fasciola hepatica: a study on the shedding of cercariae from Lymnaea truncatula raised under constant conditions of temperature and photoperiod. Parasite 1: 401-404.

Dreyfuss G., Vignoles P., Rondelaud D. 2010: Omphiscola glabra (Gastropoda, Lymnaeidae): changes occurring in natural infections with Fasciola hepatica and Paramphistomum daubneyi when this snail species is introduced into new areas. Ann. Limnol.-Int. J. Limnol. 46: 191-197.

Erhardová-Kotrlá B. 1971: The Occurrence of Fascioloides magna (Bassi, 1875) in Czechoslovakia. Academia, Prague, $155 \mathrm{pp}$.

Lorenzo M., Ramirez P., Mendez M., Alonso M., Ramos R. 1989: Reporte de Fascioloides magna Bassi, 1875 parasitando un wapiti (Cervus canadensis) en Cuba Rev. Cub. Cienc. Vet. 20: 263-266.

Morales G., Pino L.A. 1983: Infection of Lymnaea cubensis by Fasciola hepatica in a high altitude region in Venezuela. Ann. Parasitol. Hum. Comp. 58: 27-30.

Ollerenshaw C.B. 1971: Some observations on the epidemiology of fascioliasis in relation to the timing of molluscicide applications in the control of the disease. Vet. Rec. 88: 152-164.

Pybus M.J. 2001: Liver flukes. In: W.M. Samuel, M.J. Pybus and A.A. Kocan (Eds.), Parasitic Diseases in Wild Mammals. Iowa State University Press, Iowa, pp. 121-149.

Rondelaud D., Barthe D. 1987: Fasciola hepatica L.: étude de la productivité d'un sporocyste en fonction de la taille de Lymnaea truncatula. Parasitol. Res. 74: 155-160.

Rondelaud D., Fousi M., Vignoles P., Moncef M., Dreyfuss G. 2007: Optimization of metacercarial production for three digenean species by the use of Petri dishes for raising lettucefed Galba truncatula. Parasitol. Res. 100: 861-865.

Rondelaud D., Titi A., Vignoles P., Mekroud A., Dreyfuss G. 2013: Consequence of temperature changes on cercarial shedding from Galba truncatula infected with Fasciola hepatica or Paramphistomum daubneyi. Parasite 20: a10.

Rondelaud D., Vignoles P., Dreyfuss G. 2009: La Limnée Tronquée, un Mollusque d'Intérêt Médical et Vétérinaire. PULIM, Limoges, 283 pp.

Sanabria R., Mouzet R., Courtioux B., Vignoles P., Rondelaud D., Dreyfuss G., Cabaret J., Romero J. 2012: Intermediate snail hosts of French Fasciola hepatica: Lymnaea neotropica and Lymnaea viatrix are better hosts than local Galba truncatula. Parasitol. Res. 111: 2011-2016.

Sanabria R., Mouzet R., Pankrác J., Djuikwo Teukeng F.F., Courtioux B., Novobilský A., Höglund J., Kašný M., Vignoles P., Dreyfuss G., Rondelaud D., Romero R. 2013: Lymnaea neotropica and Lymnaea viatrix, potential intermediate hosts for Fascioloides magna. J. Helminthol. 87: 494-500.

Smyth J.D., Halton D.W. 1983: Physiology of Trematodes. Second Edition. Cambridge University Press, Cambridge, 432 pp.

Szmidt-Adjidé V., Rondelaud D., Dreyfuss G., Cabaret J. 1996: The effect of parasitism by Fasciola hepatica and Muellerius capillaris on the nerve ganglia of Lymnaea truncatula. J. Invertebr. Pathol. 67: 300-305.

Vignoles P., Novobilský A., Rondelaud D., Bellet V., Treuil P., Koudela B., Dreyfuss G. 2006: Cercarial production of Fascioloides magna in the snail Galba truncatula (Gastropoda: Lymnaeidae). Parasitol. Res. 98: 462-467.

ZischKE J.A. 1967: Redial populations of Echinostoma revolutum developing in snails of different sizes. J. Parasitol. 53: 1200-1204.

Received 4 July 2013

Accepted 30 November 2013 